\title{
Thermal Cracking of Low Temperature Conversion on Low Density Polyethylene Plastic Waste for Liquid Hydrocarbon
}

Thermal Cracking of Low

Temperature Conversion

Heriyanti, Lenny Marlinda, Rayandra Asyhar and Sutrisno Faculty of Science and Technology, Department of Chemistry, University of Jambi, Jambi, Indonesia

Marfizal

School of Engineering, Sekolah Tinggi Teknologi Nasional Jambi, Jambi Indonesia

\begin{abstract}
Purpose - This work aims to study the treatment of adsorbant on the increasing liquid hydrocarbon quality produced by pyrolysis low density polyethylene (LDPE) plastic waste at low temperature. The hydrocarbon distribution, physicochemical properties and emission test were also studied due to its application in internal combustion engine. This research uses pure Calcium carbonate $\left(\mathrm{CaCO}_{3}\right)$ and pure activated carbon as adsorbant, LDPE type clear plastic samples with control variable that is solar gas station.

Design/Methodology/Approach - LDPE plastic waste of $10 \mathrm{~kg}$ were vaporized in the thermal cracking batch reactor using LPG $12 \mathrm{~kg}$ as fuel at range temperature from 100 to $300^{\circ} \mathrm{C}$ and condensed into liquid hydrocarbon. Furthermore, this product was treated with the mixed $\mathrm{CaCO}_{3}$ and activated carbon as adsorbants to decrease contaminant material.

Findings - GC-MS identified the presence of carbon chain in the range of $\mathrm{C} 6-\mathrm{C} 44$ with $24.24 \%$ of hydrocarbon compounds in the liquid. They are similar to diesel (C6-C14). The $30 \%$ of liquid yields were found at operating temperature of $300^{\circ} \mathrm{C}$. The calorific value of liquid was $46.021 \mathrm{MJ} / \mathrm{Kg}$. This value was $5.07 \%$ higher than diesel as control.

Originality/value - Hydrocarbon compounds in liquid produced by thermal cracking at a low temperature was similar to liquid from a catalytic process.
\end{abstract}

Keywords LDPE, pyrolysis, liquid hydrocarbon, fuel

All papers within this proceedings volume have been peer reviewed by the scientific committee of the Malikussaleh International Conference on Multidisciplinary Studies (MICoMS 2017).

Authors of this research paper sincerely acknowledge the research grant provided by PNPB 2017 Faculty of Sains and Technology University of Jambi, Indonesia.

(C) Heriyanti, Lenny Marlinda, Rayandra Asyhar, Sutrisno, Marfizal. Published in the Emerald Reach Proceedings Series. Published by Emerald Publishing Limited. This article is published under the Creative Commons Attribution (CC BY 4.0) licence. Anyone may reproduce, distribute, translate and create derivative works of this article (for both commercial and non-commercial purposes), subject to full attribution to the original publication and authors. The full terms of this licence may be seen at http://creativecommons.org/licences/by/4.0/legalcode

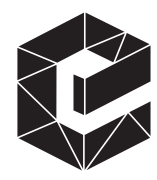

Emerald Reach Proceedings Series Vol. 1 pp. 479-486 2516-2853 DOI 10.1108/978-1-78756-793-1-00074 
Proceedings of MICoMS 2017

\section{0}

\section{Introduction}

In Indonesia there are 64 million tons of waste and 9.6 million tons of them are plastic waste. According to the Ministry of Environment and Forestry in Indonesia, the rate of used plastic bags in Indonesia is more 1 million per minute in 2016. Every year, to produce plastic bags it would need about $8 \%$ of world oil production or 12 million barrels of oil and 14 million trees (Nugraha, 2016). In fact, plastic can be converted again into fuel by pyrolysis or thermal cracking. The molecular structure of the plastic was decomposed into smaller molecules by heating process at high temperature without oxygen. Therefore, plastic with a high enough calorific value can be used as an alternative energy source that equivalent to fossil fuels such as gasoline and diesel (Velma, 2015). Surono and Ismanto (2016) processed polypropylene $(\mathrm{PP})$ and polyethylene $(\mathrm{PE})$ plastic wastes to produce plastic oil with carbon atoms close to gasoline and kerosene. Meanwhile polyethylene-terephthalate (PET) plastic did not produce oil but powdered material. Norsujianto (2014) converted plastic waste into oil indicating the hydrocarbon component in the $\mathrm{C} 4-\mathrm{C} 44$ range as a new energy fuel. According to Surono (2013), the mixed PE and PP plastics were converted into fuel oil using thermal cracking at $450^{\circ} \mathrm{C}$ for $2 \mathrm{~h}$ and condensed at temperature of $21^{\circ} \mathrm{C}$ to produce oil having equal amount of carbon atoms, i.e., C12-C17.

Generally, the crude oil produced by the pyrolysis still contain lots of contaminants. Adsorption was one way to remove the contaminants so that the quality of oil produced is better. This product can be used as fuel and chemicals. Febriani (2015) had studied natural bentonite and activated carbon of palm shells as adsorbents. Based on XRD and SEM results, the main content in bentonite in the form of Calcium carbonate $\left(\mathrm{CaCO}_{3}\right)$ succeeded in decreasing the sulfur value and increasing the calorific value.

As a consequence, the proposed work based on pyrolysis of low density polyethylene (LDPE) followed adsorption process on liquid hydrocarbon with the mixed $\mathrm{CaCO}_{3}$ and activated carbon as adsorbant has been performed in a batch reactor in a range temperature from 100 to $300^{\circ} \mathrm{C}$. This work aims to investigate the treatment of adsorbant on the increasing liquid hydrocarbon quality. The hydrocarbon distribution, physicochemical properties, and emission test were also studied due to its application in internal combustion engine. This research used pure $\mathrm{CaCO}_{3}$ and activated carbon as adsorbent, the clear LDPE plastic samples and solar from gas station as control variable.

\section{Experimental methods}

\subsection{Preparation of materials and sample}

LDPE plastic waste, i.e., clear plastic for food wrapping, trash bags and plastic bags were collected from landfills around residential areas in Jambi. The plastics before used in this study were washed with soap and dried under sunshine. To increase surface area during pyrolysis process the dried plastics were crushed into a small size. According to Wahyudi (2001), the smaller size of plastic can give the greater surface area per unit weight so that liquid product was formed quickly during the pyrolysis process.

$\mathrm{CaCO}_{3}$ and activated carbon were proanalyzed Grade from E. Merck (Germany). A $85 \%: 15 \%$ weight ratio of this mixed $\mathrm{CaCO}_{3}$ and activated carbon were used to adsorp contaminat materials in liquid product. Before it was used, the mixed materials were grounded into powder until the stability of color changing was reached. The adsorbants was analyzed by XRD to know crystal structure.

\subsection{Thermal cracking process}

Thermal cracking process on LDPE plastic waste was done according to a previous procedure (Zainuri, 2014). Plastics of $10 \mathrm{~kg}$ were vaporized in the thermal cracking batch 
reactor using LPG $12 \mathrm{~kg}$ as fuel at range temperature from 100 to $300^{\circ} \mathrm{C}$ and condensed into the product of liquid hydrocarbon.

Furthermore, the product was treated with the mixed $\mathrm{CaCO}_{3}$ and activated carbon as adsorbants to decrease contaminant material. According to a previous procedure (Puspadiningrum, 2007), the adsorbant of $2.5 \mathrm{~g}$ was loaded in flask and followed liquid product of $250 \mathrm{~mL}$ under stiring at temperature of $30^{\circ} \mathrm{C}$ for $2 \mathrm{~h}$. After finishing this process, filtrate was separated from adsorbant solid. The obtained filtrate was denoted as the liquid hydrocarbon. Meanwhile, physicochemical analysis such as the calorific value and density were applied on the liquid hydrocarbon to determine its properties for application as fuel. With the same treatment on the liquid product, petroleum diesel was used as control variable.

The caloarific value was obtained through a bomb calorimeter (Model: type 5E-C5500 Automatic Calorimeter AXT). Density was determined by pycnometric bottles. Beside that, diesel like hydrocarbon composition in liquid product were identified by gas chromatography-mass spectroscopy (GC-MS) with tipe QP2010 SE. The GC system was programmed at $30^{\circ} \mathrm{C}$ and increased to $330^{\circ} \mathrm{C}$ at $10^{\circ} \mathrm{C} / \mathrm{min}$ for $30 \mathrm{~min}$ of total run time. Some compounds in liquid hydrocarbon were ionized at sources ion temperature of $260^{\circ} \mathrm{C}$ and a mass electron range of 40-500 were used to analysis process. The chromatograms of hydrocarbons were shown at different retention time and identified using the W9N11 MS library mass spectral library of data.

\subsection{Emission test of liquid hydrocarbon}

To minimize negative impact on environment the emission gas test was carried out using a motor engine and liquid hydrocarbon was used as fuel. According to a previous procedure (Norsujianto, 2014), this test was applied in a motor engine that using oil from LDPE plastic pyrolyzed before and after adsorption. Waste emission gas was identified by a gas analyzer. The emission test on motor vehicle exhaust were the process of measuring the levels of the compounds contained in motor vehicle exhaust emissions.

\section{Results and discussion}

When the temperature of pyrolysis increased from 100 to $130^{\circ} \mathrm{C}$, plastic solids began to melt indicated by vapor and droplets of plastic oil that was still mixed with impurities. The increase of temperature to $220^{\circ} \mathrm{C}$, plastic oil of $750 \mathrm{~mL}$ was obtained. Finally, when temperature was raised to $300^{\circ} \mathrm{C}$, the process was stopped. This is due to leakage in the thermal cracking batch reactor. This occurred after a pyrolysis process lasted for $2.05 \mathrm{~h}$ and $3,100 \mathrm{~mL}$ of plastic oil was obtained. A yield of $30 \%$ was reached. It was similar to Sarker et al. (2012), plastic oil yield of $40 \%$ was obtained at $325^{\circ} \mathrm{C}$. Figure 1 shows plastic oil dan residual pyrolysis solids. This liquid has characteristics, i.e yellowish brown, thick and very sharp smell. The residue color seen in brown milk. This residue has also a waxy texture as shown in Figure 1b.

When Figures 1 and 2 were compared, the difference in color between the clear LDPE plastic oil before and after adsorption was visible. This indicated that the mixed $\mathrm{CaCO}_{3}$ and activated carbon in bleaching.can bind substances causing undesirable color and odor.

\subsection{Characterization of liquid hydrocarbon}

Physical and chemical properties of liquid hydrocarbon. The calorific value of petroleum diesel and liquid hydrocarbon was listed in Table 1 . It can be seen that the calorific value of liquid hydrocarbon increased when the value was compared with petroleum diesel. (Dewangan et al., 2016) also reported that it can be caused by the increase in $\mathrm{H} / \mathrm{C}$ ratio. The 
Proceedings of MICoMS 2017

\section{2}

\section{Figure 1.}

Plastic Oil (a) and Residual Pyrolysis Solids (b)

\section{Figure 2.}

Liquid Hydrocarbon from Plastic Oil Treated with Adsorbant (a) and Petroleum Diesel as Control Variable (b)

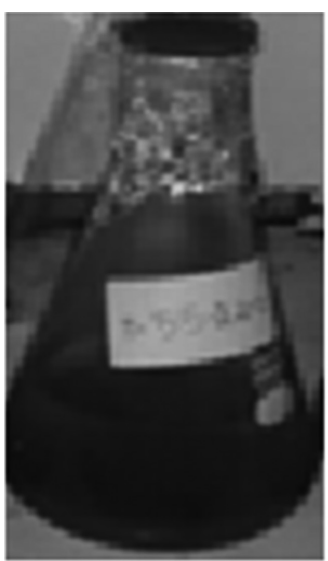

(a)

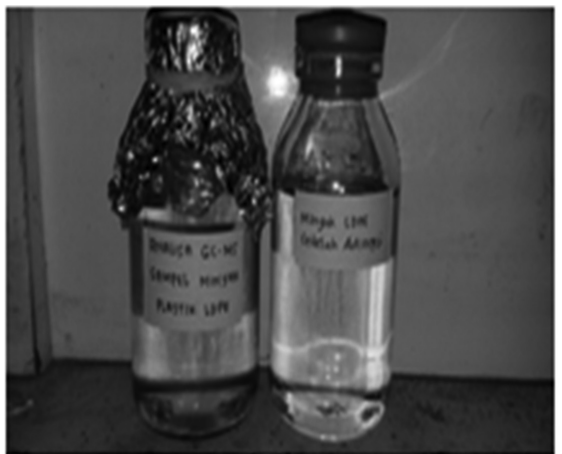

(a)

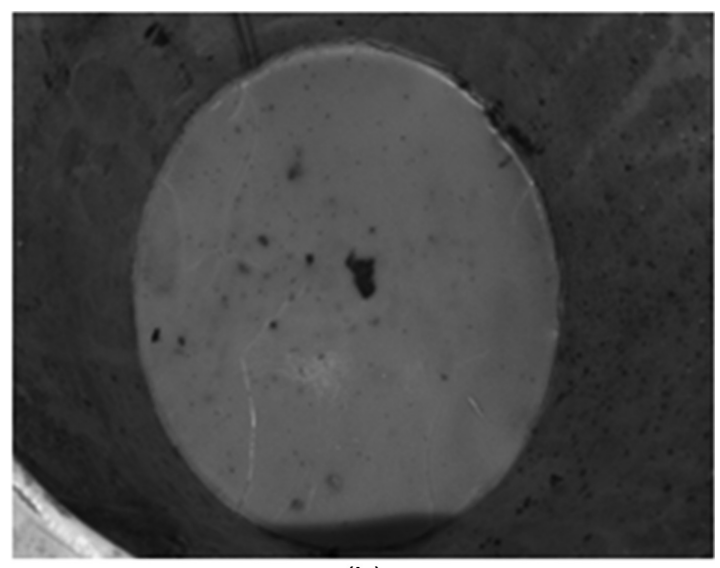

(b)

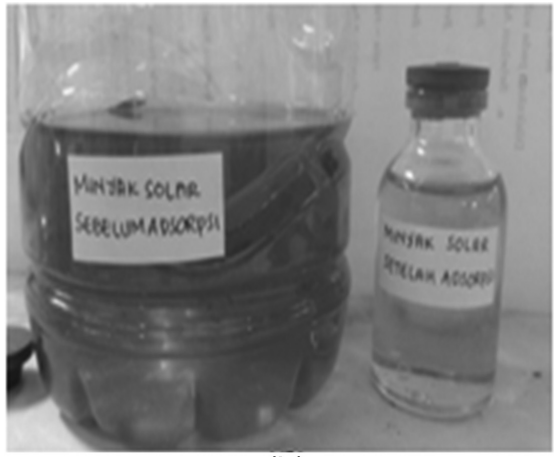

(b)
Table 1.

Physical Properties of Liquid Products

\begin{tabular}{llllll}
\hline & \multicolumn{2}{c}{ Properties Before Adsorption } & & \multicolumn{2}{c}{ Properties After Adsorption } \\
\cline { 2 - 3 } Sample & $\begin{array}{c}\text { Density } \\
(\mathrm{g} / \mathrm{mL})\end{array}$ & $\begin{array}{c}\text { Calorific Value } \\
(\mathrm{MJ} / \mathrm{kg})\end{array}$ & & $\begin{array}{c}\text { Density } \\
(\mathrm{g} / \mathrm{mL})\end{array}$ & $\begin{array}{c}\text { Calorific Value } \\
(\mathrm{MJ} / \mathrm{kg})\end{array}$ \\
\hline Liquid hydrocarbon & 0.7133 & 46.021 & & 0.6903 & 46.624 \\
Petroleum Diesel & 0.7683 & 43.800 & & 0.7483 & 44.417 \\
\hline
\end{tabular}

hydrocarbon content and oxygen content play a significant role in controlling the calorific value of oil.

Calorific value of liquid hydrocarbon after adsorption was increased by $60.3 \%$ likewise with petroleum diesel after adsorption increased to $61.7 \%$. This indicated that the adsorption process has a major effect on increasing the calorific value of the fuel. The adsorption by the mixed $\mathrm{CaCO}_{3}$ adsorbent and activated carbon can decrease impurities content that can influence the calorific value. 

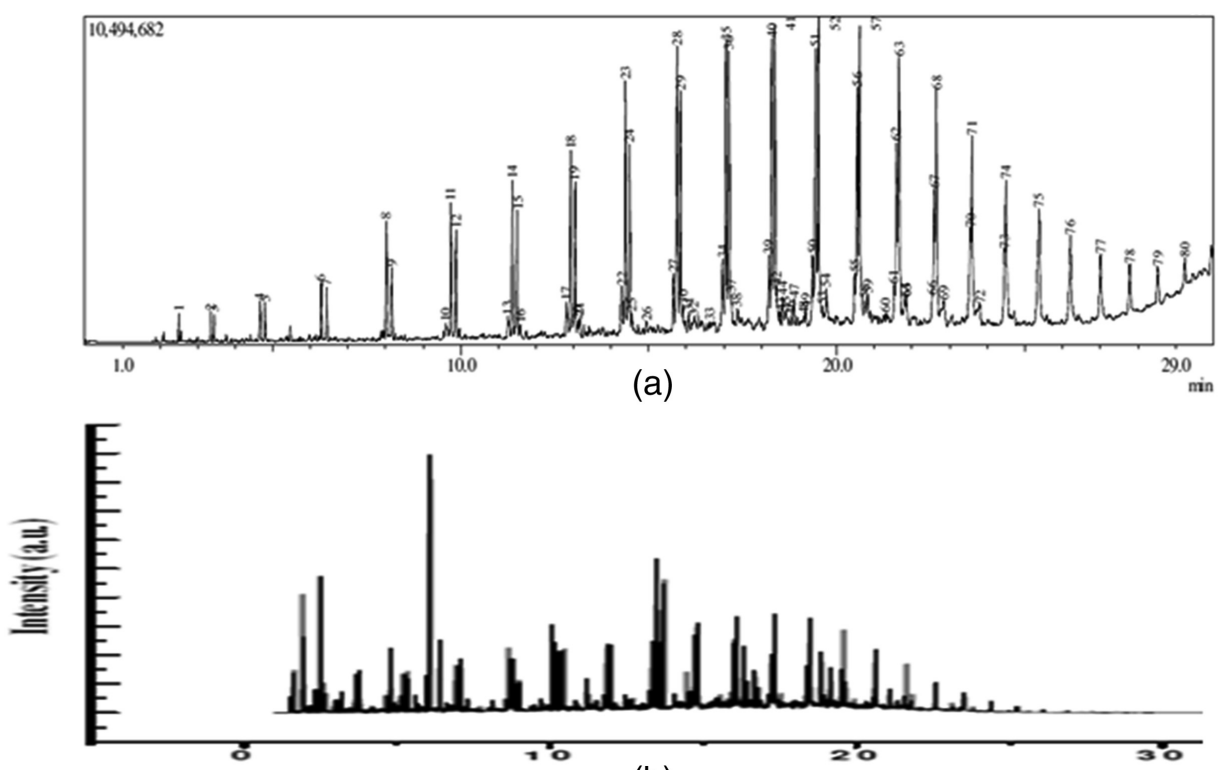

(b)
Thermal

Cracking of Low

Temperature Conversion 483

Figure 3.

The

Chromatographic

Peaks of Liquid Hydrocarbon from LDPE Pyrolyzed at Range Temperature of (a) $100-300^{\circ} \mathrm{C}$ in this Work, (b) 100$400^{\circ} \mathrm{C}$, reported by Sarker et al. (2012)

GC-MS analysis of liquid hydrocarbon. Figure 3 shows the chromatograms of liquid product produced from pyrolyzed LDPE at $300{ }^{\circ} \mathrm{C}$. It was detected 80 of peaks in the range of retention time. It can be also observed that the peak positions in Figure 3 were almost similar to liquid from pyrolyzed LDPE by Yang et al. (2012). It was also the same result reported by a previous study (Sarker et al., 2012), in the range of retention time less than 18 min, the carbon distribution ranging from $\mathrm{C} 6$ to $\mathrm{C} 20$ was detected. For the retention time longer than $18 \mathrm{~min}$, long-chain hydrocarbon (alkenes) such as octadecene became the main compounds in the liquid hydrocarbon. It should be noted that only the peaks corresponding to the hydrocarbons in the liquid hydrocarbon derived from the pyrolysis of LDPE. The information of main peaks such as retention time and compound name are listed in Table 2

\begin{tabular}{|c|c|c|c|c|c|c|c|}
\hline Peak & $\begin{array}{c}\text { Retention } \\
\text { Time } \\
\text { (min) }\end{array}$ & $\begin{array}{c}\text { Area } \\
\%\end{array}$ & $\mathrm{~m} / \mathrm{z}$ & $\begin{array}{l}\text { Chemical } \\
\text { Formula }\end{array}$ & Compound & $\mathrm{m} / \mathrm{z}$ & \\
\hline 52 & 19,508 & 4,33 & 266 & $\begin{array}{l}\mathrm{C}_{18} \mathrm{H}_{38} \\
\mathrm{C}_{15} \mathrm{H}_{32} \\
\mathrm{C}_{14} \mathrm{H}_{30} \\
\mathrm{C}_{20} \mathrm{H}_{42} \\
\mathrm{C}_{21} \mathrm{H}_{14} \mathrm{FEN}_{2} \mathrm{O}_{3}\end{array}$ & $\begin{array}{l}\text { n-Octadecana } \\
\text { h-Pentadecana } \\
\text { n-tetradecana } \\
\text { n-Eicosane } \\
{[\mathrm{N} \text {-(phenyl-2-pyridinylmethylene) }} \\
\text { benzenamine-N,N] }\end{array}$ & $\begin{array}{l}254 \\
212 \\
198 \\
282 \\
398\end{array}$ & \\
\hline 57 & 20,603 & 4,37 & 276 & $\begin{array}{l}\mathrm{C}_{19} \mathrm{H}_{40} \\
\mathrm{C} 21 \mathrm{H} 14 \mathrm{FEN} 2 \mathrm{O} 3\end{array}$ & $\begin{array}{l}\text { n-Nonadecana } \\
{[\mathrm{N} \text {-(Phenyl-2- }} \\
\text { 2pyridinylmethylene) } \\
\text { benzenamine-N,N] } \\
\text { n-Eicosane } \\
\text { n-Oktadecana }\end{array}$ & $\begin{array}{l}268 \\
398\end{array}$ & $\begin{array}{r}\text { Table } 2 . \\
\text { The Retention Time } \\
\text { and Compounds of } \\
\text { Main Peaks Shown in } \\
\text { Figure } 3\end{array}$ \\
\hline
\end{tabular}


Proceedings of indicating that liquid hydrocarbon composition (C14-C21) was similar with petroleum diesel MICoMS 2017 (C15-C18).

\subsection{Characterization of adsorbant}

In this research, characterization of the mixed $\mathrm{CaCO}_{3}$ and activated carbon before and after

484 adsorption was done. This was done to see the changes that occur in the adsorbant after the adsorption process. Figure 4 shows that the diffraction peak characteristic of calcite was clearly observed at $2 \theta=29.23^{\circ}$ dan $29.39^{\circ}$, corresponding to JCPDS $47-1743$. It indicated that the adsorption did not change cristal structure of calcite significantly.

\subsection{Emission test of liquid hydrocarbon}

Figure 5 shows the highest emission gas produced by liquid hydrocarbon is $\mathrm{C}_{\mathrm{x}} \mathrm{H}_{\mathrm{y}}$ gas. This was due to incomplete combustion so that $\mathrm{C}_{\mathrm{x}} \mathrm{H}_{\mathrm{y}}$ gas produced was higher than $\mathrm{CO}, \mathrm{NO}, \mathrm{NO}_{2}$,

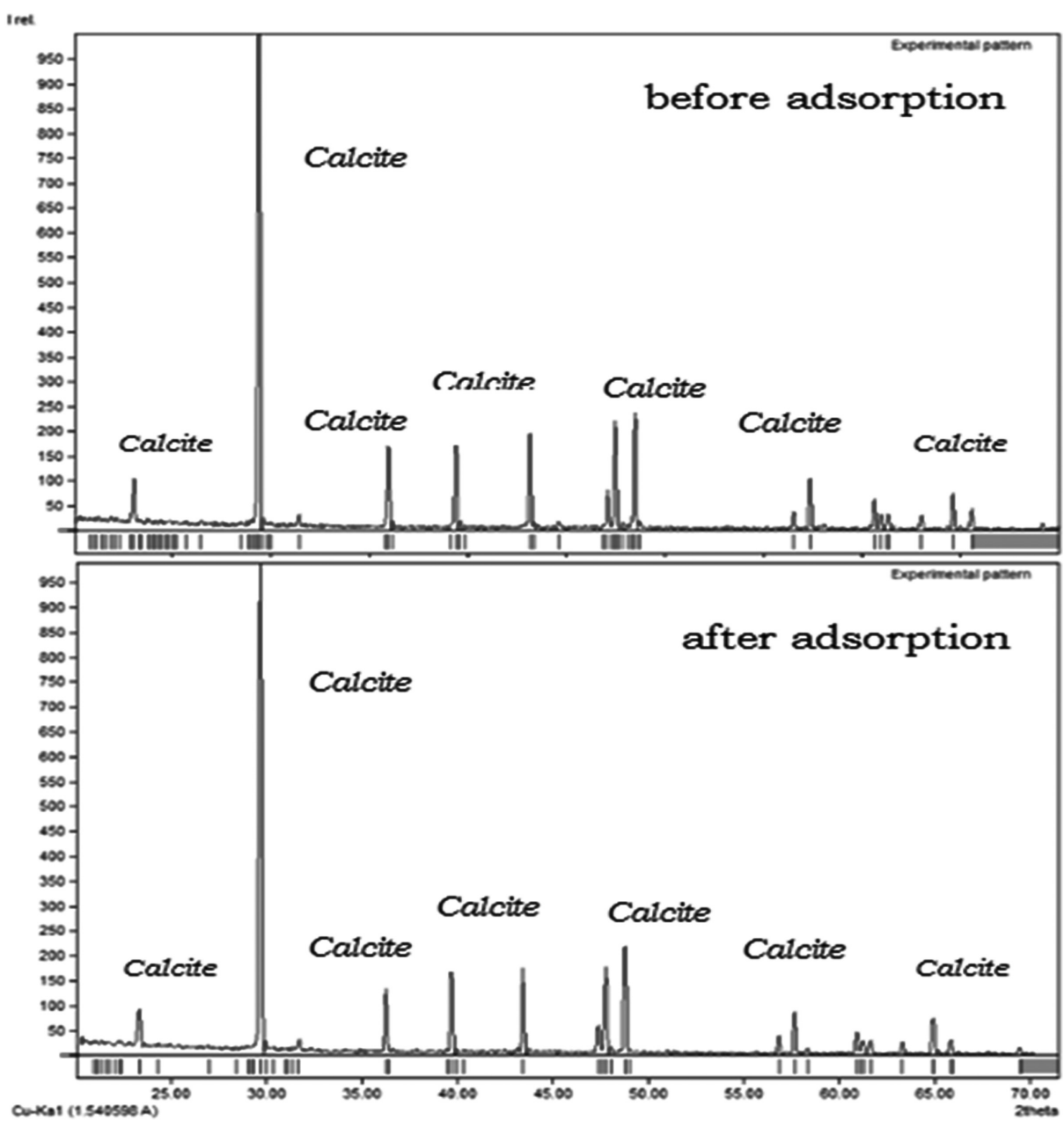

Figure 4.

XRD Pattern of the Mixed $\mathrm{CaCO}_{3}$ and Activated Carbon before Adsorption and After Adsorption 
$\mathrm{NO}_{\mathrm{x}}$, and $\mathrm{SO}_{\mathrm{x}}$. However, it can be seen that the gas concentration produced by liquid hydrocarbon after adsorption had been decreased. It can be concluded that the adsorption can give a good effect on reducing of the concentration of emission gas produced by motor engine. In this gas exhaust emission test, $\mathrm{SO}_{2}$ produced was $0 \mathrm{ppm}$. It was possibly because the plastic raw material used was clear LDPE plastic. In addition, the $\mathrm{SO}_{2}$ gas produced was still in small concentration so it cannot be detected by the exhaust gas gauge. Similarly, $\mathrm{NO}_{2}$ gas produced was $0 \mathrm{ppm}$. Furthermore, $\mathrm{CH}_{4}$ and $\mathrm{CO}_{2}$ gas emissions are listed in Figure 6.

Figure 6 shows the emission of $\mathrm{CH}_{4}$ gas produced on liquid hydrocarbon after adsorption was decreased when compared with before adsorption. It indicated that the adsorption can decrease methane concentration from while the $\mathrm{CO}_{2}$ gas produced increased. It can be said that the combustion happened was already good. According to Guntur et al. (2011), the $\mathrm{CO}_{2}$ concentration indicated a completely burning conditions at the burning room. The higher the $\mathrm{CO}_{2}$ concentration, the better the combustion process.
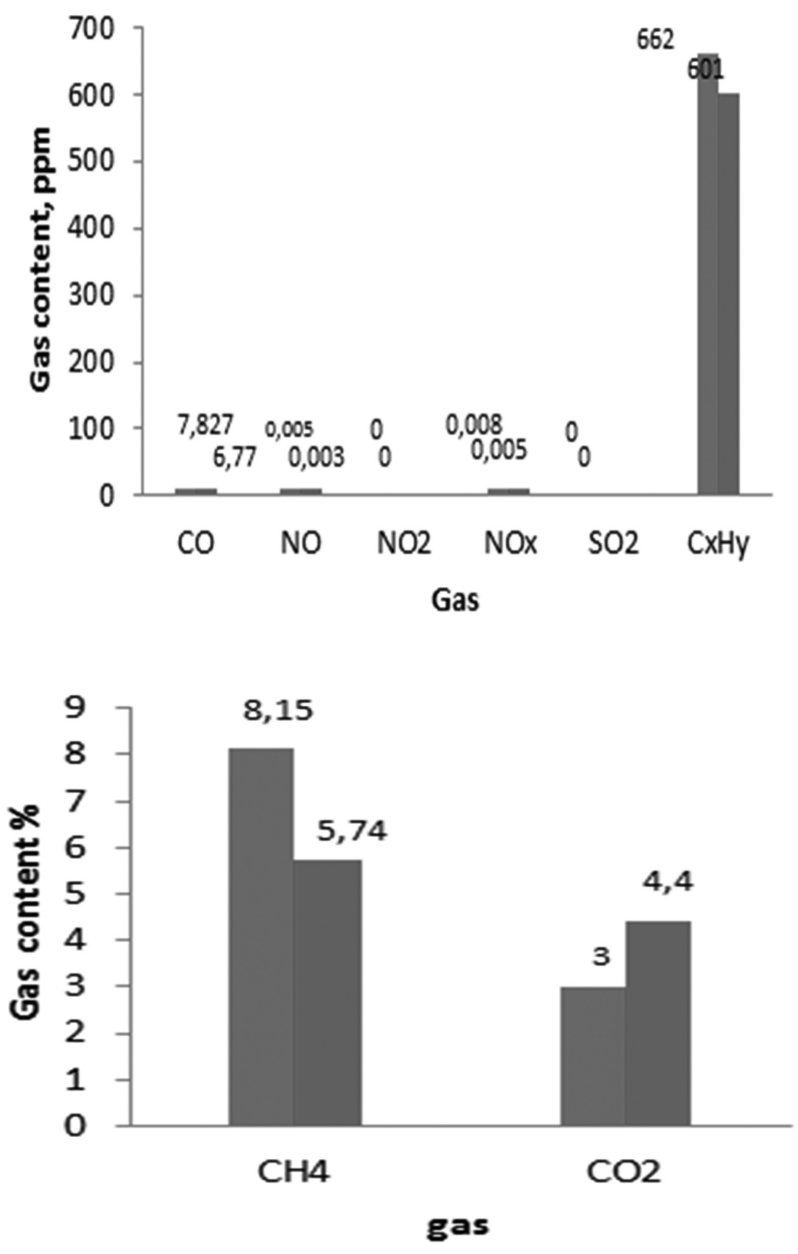

Thermal Cracking of Low

Temperature Conversion 485
Figure 5.

Exhaust Gas Emissions of Liquid Hydrocarbon (Blue: Before Adsorption, Red: After Adsorption)
Figure 6. $\mathrm{CH}_{4}$ and $\mathrm{CO}_{2} \mathrm{Gas}$ Emissions of Liquid Hydrocarbon (Blue: Before Adsorption, Red: After Adsorption) 


\section{Proceedings of 4 . Conclusions}

MICoMS 2017 According to the results of GC-MS, liquid hydrocarbon from pyrolyzed LDPE had a C6-C14 range hydrocarbon. Liquid hydrocarbon before adsorption was more wasteful than liquid hydrocarbon after adsorption. Adsorption using a mixture of $85 \% \mathrm{CaCO}_{3}$ and $15 \%$ activated carbon can reduce exhaust gas emissions.

\section{6}

\section{References}

Dewangan, A., Pradhan, D. and Singh, R.K. (2016). "Co-Pyrolysis of Sugarcane Bagasse and LowDensity Polyethylene: Influence of Plastic on Pyrolysis Product Yield”. Fuel Vol. 185, pp. 508516.

Febriani, S. (2015). Pirolisis Minyak Plastik Jenis Polipropilena dan Adsorpsi Dari Campuran Bentonit dan 30\% Karbon Teraktivasi $\mathrm{H}_{3} \mathrm{PO}_{4}$. Program Studi Kimia Fakultas Sains dan Teknologi, Universitas Jambi, Jambi.

Guntur, R.,Kumar D., Vijaya R K. (2011), "Experimental Evaluation of a Diesel Engine with Blends of Diesel Plastic Pyrolisis Oil”. Engg Journals Publications. Journal of IJEST, Vol. 3, No. 6.

JCPDS. (1998). Calcium Carbonate ( $\mathrm{CaCO}_{3}$ ). International Centre for Diffraction Data, pp. 47-1743.

Mohseni, K. (2007). "Characterization of Precipitated Calcium Carbonate (PCC) Compounds on the Basis of Powder X-ray Diffraction Data”. Disertation. Iran-Teheran: Universitat Karlsruhe (TH).

Norsujianto, T. (2014). "Konversi Limbah Plastik Menjadi Minyak Sebagai Bahan Bakar Energi Baru Terbaharukan”. Jurnal Element, Vol. 1, No. 1, pp. 5-9.

Nugraha, I. Indonesia PakaiKantongPlastik 1 JutaTiapMenit.www.mongabay.co.id; February 10th, 2016.

Puspadiningrum, S. (2007). Pengaruh Jenis Adsorben pada Pemurnian Biodiesel dari Minyak Jarak Pagar (Jatropha curcas L). Fakultas Teknologi Pertanian, Institut Pertanian Bogor, Bogor.

Sarker, M., Mamunor, R.M.M., Rahman Md., S and Molla, M. (2012). "Conversion of Low Density Polyethylene(LDPE) and Polypropylene (PP) Waste Plastics into Liquid Fuel Using Thermal Cracking". British Journal of Environment \& Climate Change, Vol. 2, No. 1, pp. 1-11.

Surono, U.B. and Ismanto. (2016). "PengolahanSampahPlastikJenis PP, PET dan PE MenjadiBahanBakarMinyakdanKarakteristiknya”, JurnalMekanikadanSistemTermal, Vol. 1 No. 1, pp. 32-37.

Surono, U.B. and Ismanto. (2016). "Pengolahan Sampah Plastik Jenis PP, PET dan PE Menjadi Bahan Bakar Minyak dan Karakteristiknya”. Jurnal Mekanika dan Sistem Termal, Vol. 1, No. 1.

Velma, N. (2015), "StudiBerbagaiMetodePembuatan BBM dariSampahPalstikjenis LDPE dan PVC denganMetode Thermal dan Catalytic Cracking (Ni-Cr/Zeolit)". JurnalTeknis, Vol. 10 No. 3, pp. 137-144.

Wahyudi, I. (2001). "Pemanfaatan Blotong Menjadi Bahan Bakar Cair Dan Arang Dengan Proses Pirolisis”. Jurusan Teknik Lingkungan FTSP UPN “Veteran” Jatim

Yang, J., Jenny, R., Wahyu, B. W., Karnjanakom, S., Malinee, K., Xiaogang, H., Abuliti, A., and Guan, G. (2016). "Fast Co-Pyrolysis of Low Density Polyethylene and Biomass Residue for Oil Production”. Energy Conversion and Management, Vol. 120, pp. 422-429.

Zainuri, F. (2014). "Pirolisis Sampah Plastik Hingga Suhu $900^{\circ} \mathrm{C}$ sebagai Upaya Menghasilkan Bahan Bakar Ramah Lingkungan”. Jurusan Teknik Mesin Politeknik Negeri Jakarta, Jakarta

\section{Corresponding author}

Sutrisno can be contacted at herasutrisno@unja.ac.id 